\title{
Progranulin and TDP-43: Mechanistic Links and Future Directions
}

\author{
Samir Kumar-Singh
}

Received: 30 June 2011 / Accepted: 8 August 2011 /Published online: 24 August 2011

(C) The Author(s) 2011. This article is published with open access at Springerlink.com

\begin{abstract}
Loss-of-function mutations in the multifunctional growth factor progranulin (GRN) cause frontotemporal lobar degeneration (FTLD) with TDP-43 protein accumulation. Nuclear TDP-43 protein with key roles in RNA metabolism is also aggregated in amyotrophic lateral sclerosis (ALS), suggesting that ALS and FTLD constitute a broad disease continuum. However, the fact that mutations in GRN are associated with FTLD, while mutations in TDP-43 cause a preferential loss of motor neurons resulting in ALS-end of the disease spectrum, suggests involvement of both cell-autonomous and non-autonomous mechanisms. Studies on animal models and in vitro studies have been instrumental in understanding the link between GRN and TDP-43 and also their role in neurodegeneration. For instance, in mouse models, allelic deficiencies of Grn do not recapitulate human pathology of TDP-43 brain accumulations, but embryonic neurons derived from these mice do show abnormal TDP-43 accumulation after additional cellular challenges, suggesting that TDP-43 changes observed in GRN mutation carriers might also relate to stress. Recent results have shown that the dual action of GRN in growth modulation and inflammation could be due to its negative regulation of TNF- $\alpha$ signaling. In addition, GRN also interacts with sortilin and is endocytosed, thereby regulating its own levels and possibly also modulating the turnover of other proteins including that of TDP-43. Accumulating evidence suggests that TDP-43 abnormal cellular aggregation causes a possible gain of function, also suggested by recently constructed mouse models of TDP-43 proteinopathy;
\end{abstract}

\footnotetext{
S. Kumar-Singh $(\varangle)$

Laboratory of Molecular and Cellular Neuropathology,

University of Antwerp,

Universiteitsplein 1,

2610 Antwerpen, Belgium

e-mail: samir.kumarsingh@ua.ac.be
}

however, it would be inconvincible that sequestration of physiological TDP-43 within cellular aggregates observed in patients would be innocuous for disease pathogenesis. This review discusses some of these data on the possible link between GRN and TDP-43 as well as mechanisms involved in TDP-43-led neurodegeneration. Continued multitiered efforts on genetic, cell biological, and animal modeling approaches would prove crucial in finding a cure for GRN-related diseases.

Keywords FTLD · ALS · Progranulin · TDP-43 · Signaling · Transgenic mouse model $\cdot$ Pathogenesis

\section{FTLD—Progranulin}

Frontotemporal dementia (FTD) is the second most common form of cortical dementia in the population under the age of 65 with a prevalence of 3-25 cases per 100,000 people (Ratnavalli et al. 2002). Clinical FTD is characterized by changes in personality/behavior and/or language dysfunction, but patients may also display movement abnormalities such as Parkinsonism or motor neuron disease (Brun et al. 1994; Neary et al. 1998). The neuropathology associated with FTD and other closely related clinical entities such as progressive non-fluent aphasia and semantic dementia is heterogeneous but shares a feature of relatively selective degeneration of the frontal and temporal lobes (frontotemporal lobar degeneration, FTLD) (Trojanowski and Dickson 2001; Mackenzie et al. 2009). Many patients of FTD showing tau deposits (FTLD- $\tau$ ) and mutations within the microtubuleassociated protein tau (MAPT) gene were earlier identified in these FTLD- $\tau$ families linked to chromosome 17q21-22 (Hutton et al. 1998; Spillantini et al. 1998; Poorkaj et al. 1998). However, the nontauopathy disorders where ubiquiti- 
nated protein inclusions occur within nucleus and cytoplasm of neuronal and glial cells have been shown to be much more common and also representing a clinically, genetically, and pathologically highly heterogeneous group (FTLD-U) (Josephs et al. 2004; Hodges et al. 2004; Mackenzie et al. 2009; Seelaar et al. 2011).

The past few years witnessed enormous progress in understanding the pathological complexity and in identifying the genetic etiologies of this complex disorder. Intense genetic studies led to the identification of valosin-containing protein gene $(V C P)$ on chromosome 9p21-p12 (Watts et al. 2004) and the charged multivesicular body protein $2 \mathrm{~B}$ gene (CHMP2B) on chromosome 3p13 (Skibinski et al. 2005). VCP and CHMP2B are involved in protein turnover in ubiquitin-proteasome (Ub-Pr) and/or endososome-lysosomal pathways underscoring the importance of a proper protein turnover for neuronal function and viability (Babst et al. 2002; Gitcho et al. 2009b). However, it was the landmark discovery of progranulin/GRN mutations in the remaining FTLD-U families in 2006 (Baker et al. 2006; Cruts et al. 2006) that was crucial in so many respects. First, it turned out that GRN mutations are the commonest causal genetic factor responsible for up to $10 \%$ of the FTD cases (Baker et al. 2006; Cruts et al. 2006). Second, identification of GRN mutations was particularly intriguing as it provided an explanation for the amazing coincidence of the presence of two important genes on chromosome 17q21-22 linked to the same disease phenotype. Lastly, GRN with a well-known prior role in cancer stands out as a textbook example where a molecule could be causally linked to two extreme ends of a disease spectrum, on one end of which is somatic cancer with uncontrolled division and, on the other, degeneration of postmitotic neurons. This suggests that "subtle" growth modulators, deficiency of which is not embryonically lethal or developmentally challenging, should be further explored for their involvement in age-related neurodegeneration. It also now appears that those afflicted with a neurodegenerative disorder have a reduced incidence of cancers and vice versa (Plun-Favreau et al. 2010).

GRN was independently isolated by several laboratories (Plowman et al. 1992; Zhou et al. 1993; Baba et al. 1993) as a 593-amino-acid-secreted glycoprotein composed of a signal peptide followed by 7.5 tandem repeats of a 12 cysteinyl granulin motif that can be proteolytically cleaved to form a family of 6-kDa granulin peptides (grn) (He and Bateman 2003) (Fig. 1a). Both GRN and grn-peptides serve as multifunctional secreted growth factors playing key roles in development, cell cycle progression, cell motility, neuritic outgrowth, wound repair, and inflammation (He and Bateman 2003; Van Damme et al. 2008; Ahmed et al. 2007). GRN is expressed in a wide variety of tissues including neurons of cerebral cortex, hippocampus, and cerebellum (Daniel et al. 2000; Ahmed et al. 2007) (Fig. 2a). A high expression of GRN is also noted in a great variety of cancer cell lines as well as in clinical specimens of breast, ovarian, and renal cancers and in glioblastomas (Liau et al. 2000; He and Bateman 2003). Although ultrastructural studies identified the fibrillar nature of the FTLD-U inclusions (Pirici et al. 2006;
Fig. 1 Progranulin and TDP-43 structure and processing. a The top part of the figure represents the progranulin protein (human GRN; rodent Grn) and the bottom part shows the consensus sequence of the processed granulin peptides (grn); $A-G$ represent granulin peptides and $p$ represents paragranulin. b Structure of TDP-43 showing different domains of the protein and select mutations mostly clustered in the glycine-rich $\mathrm{C}$ terminus of TDP-43. The lower panel shows TDP-43 processing into $\sim 35-\mathrm{kDa}$ and different $\sim 25-$ $\mathrm{kDa}$ species identified or speculated to exist in human FTLD/ ALS patients. Drawn to scale

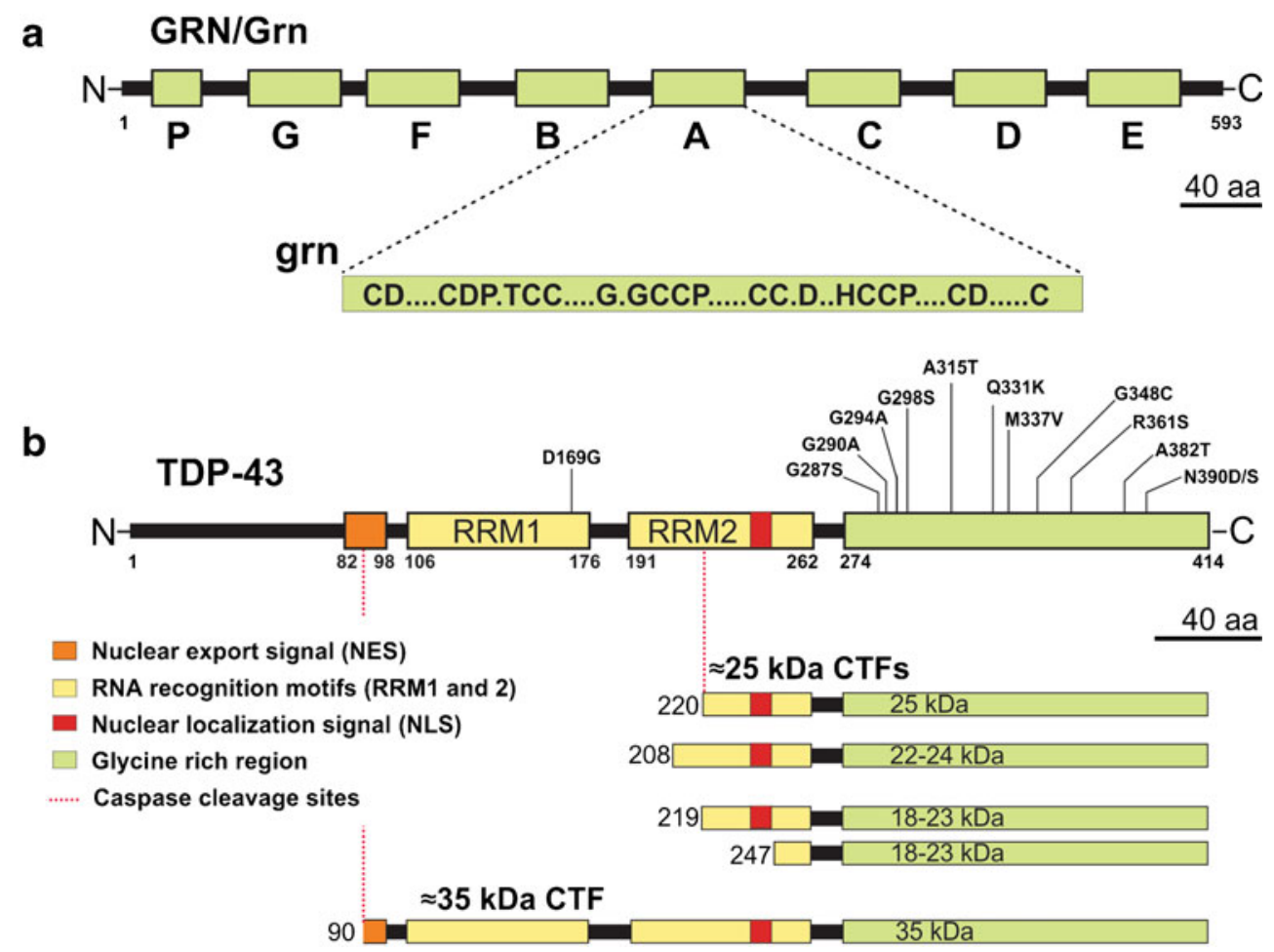


Lin and Dickson 2008), the building blocks of the ubiquitinated protein(s) remained unknown (Forman et al. 2006; Pirici et al. 2006).

\section{TDP-43 as a Molecular Substrate in FTLD and ALS}

It was yet another coincidence that the principal component of ubiquitin ${ }^{+}$inclusions in FTLD-U that had hitherto eluded us for so long was also identified in the year 2006 by biochemical enrichment techniques as TAR DNA-binding protein (TDP-43) (Neumann et al. 2006; Arai et al. 2006) (Fig. 2b).

TDP-43 is a $43-\mathrm{kDa}$ or 414-amino-acid nuclear protein, encoded by the TARDBP gene on chromosome 1 . The gene was initially cloned from a genomic screen for cellular factors that bind to the TAR DNA of HIV type 1 (Ou et al. 1995) and was also identified independently as part of a complex involved in the splicing of the cystic fibrosis transmembrane conductance regulator gene (Buratti and Baralle 2001). As a member of the heterogeneous ribonucleoprotein (hnRNP) family, TDP-43 subserves a variety of functions in regulation of transcription and splicing and in RNA stability, functions that might be as diverse and perhaps more critical than those subserved by GRN (Buratti and Baralle 2008; Lagier-Tourenne et al. 2010). TDP-43 is composed of two tandem RNA recognition motifs (RRM1 and RRM2) followed by a glycine-rich carboxyl terminus (Fig. 1b). Both RRMs retain nucleic acid binding properties, yet only RRM1 appears essential for RNA splicing (Buratti and Baralle 2001). In addition, the protein also has a nuclear localization signal and a nuclear export signal as
TDP-43 shuttles continuously between nucleus and cytoplasm (Ayala et al. 2008).

Interestingly, TDP-43 was not only a core component of the neurodegenerative mechanism(s) involved in FTLD-U (now called FTLD-TDP) but also in ALS and ALS-FTLD, further strengthening the premise that ALS and FTLD are part of a broad disease continuum (Neumann et al. 2006; Arai et al. 2006; Mackenzie et al. 2009). Recent studies have shown that TDP-43 pathology could also be observed in a spectrum of other neurodegenerative disorders, including Alzheimer's disease (AD), Guam Parkinson dementia complex, and Lewy body disease (Dickson 2008). For instance, $\sim 30 \%$ of AD patients show TDP-43 pathology, suggesting that TDP-43 might have even a broader role in neurodegeneration (Dickson 2008). Thus, 2006 was a fruitful year bringing a major shift in our understanding of FTLD pathogenesis and setting a stage for functional studies to understand how GRN causal mutations lead to TDP-43 pathology and downstream events.

\section{GRN Has a Loss-of-Function Disease Mechanism}

Mechanistically, the simplest piece in the FTLD-TDP pathogenesis puzzle is that GRN causal mutations cause a loss of its function. All mutations described so far in GRN have been either simple loss-of-function mutations or mutations that likely render GRN less active or ineffective. The first type of $G R N$ mutations are complete or near-complete deletions of $G R N$ gene (Gijselinck et al. 2008; Rovelet-Lecrux et al. 2008). The second types are those where the transcripts do not leave the nucleus, such as splice-donor site mutations
Fig. 2 Progranulin and TDP-43 immunoreactivity in human and rodent brains. Progranulin immunoreactivity in a human (a) and a rodent brain (b) showing that although GRN immunoreactivity is strongly present in microglia (arrows in b), neuronal punctate immunoreactivity is also characteristically present in the cortical brain regions. c TDP-43 reactivity in a FTLD patient showing that TDP-43 reactivity is not only absent in a cell with TDP-43 inclusion ("nuclear clearing") but is also absent to weak in some cells without inclusions. d Similar observations are also made in rodent brain showing highly variable TDP-43 expression in the nucleus. Scale bar, $20 \mu \mathrm{m}$
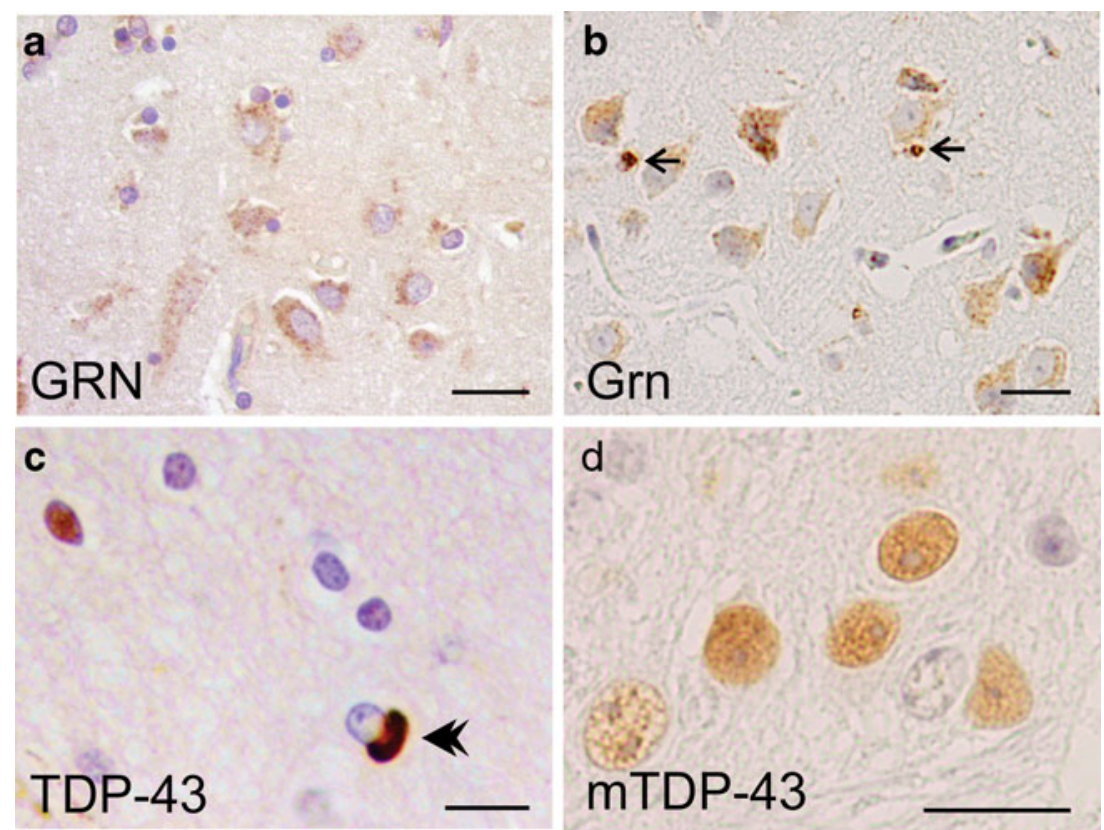
that lead to destruction of the unspliced transcript within nucleus (Cruts et al. 2006). The third types are those where the mutant transcript reaches the cytoplasm but leads to nonsense-mediated decay due to frameshift or nonsense mutations (Baker et al. 2006; Maquat 2004). This type also includes mutations in the Met start codon, which disrupt the Kozak sequence and result in a substantial reduction in GRN expression (Baker et al. 2006; Cruts et al. 2006; Gass et al. 2006). The fourth types are those where the protein is mislocalized such as those caused by signal peptide mutations (Mukherjee et al. 2006). The fifth class includes GRN coding variants (Gass et al. 2006; van der Zee et al. 2007; Mukherjee et al. 2008) that might cause loss of function of the mutant GRN by subtle structural changes, or by reduced protein production or secretion (Shankaran et al. 2008).

And finally, a subtle loss of GRN levels could also result from variants in the regulatory region of $G R N$ or in cis or transacting elements, and these might contribute as a susceptibility factor for the development of FTLD-TDP in individuals who do not carry $G R N$ causal mutations (Rademakers et al. 2008; Galimberti et al. 2010; Carrasquillo et al. 2010; Van Deerlin et al. 2010). For instance, GRN has been shown to be regulated by microRNA (miRNA). miRNAs are short RNA molecules that bind to the 3'untranslated region (UTR) of the target mRNA and silence genes via mRNA degradation or, when the complementation between the miRNA and target mRNA sequence is incomplete, by preventing mRNA from being translated (Bartel 2009). A common genetic variant (rs5848) located in the 3'-UTR of GRN was shown to be a strong binding site for miR-659 and significantly increased the risk of developing FTLD-U and also of hippocampal sclerosis that commonly accompanies many neurodegenerative processes including FTLD (Rademakers et al. 2008; Dickson et al. 2010). Other miRNAs are also being described as those that could potentially bind to $G R N$ and regulate its levels including miR-107 identified in a high-throughput experimental microRNA assay (Wang et al. 2010).

Genome-wide association studies have also identified FTLD-TDP-associated risk alleles. Importantly, these studies led to the identification of TMEM106B, a single-pass transmembrane protein that increases the risk of FTLD-TDP by modulating GRN levels (Van Deerlin et al. 2010). Cellular or tissue factors might also regulate GRN levels by modulating its turnover. GRN processing into grn-peptides by elastase is modulated by secretory leukocyte protease inhibitor (SLPI) by either directly binding and blocking the elastase or by sequestering grn-peptides from the enzyme (Zhu et al. 2002). GRN and its grn-peptides might at times have opposing functions (Zhu et al. 2002), and it would be interesting to study factors that increase the levels or the activity of elastase and/or SLPI that might in turn modulate
GRN levels in brain parenchyma thereby increasing the risk of developing FTLD-TDP.

\section{GRN Cell Signaling}

While loss of GRN levels and/or its function might be central to FTLD-TDP etiopathogenesis, which of these many functions is most critical to disease remains unknown. A part of this quandary is also that the signaling pathways involved in GRN-mediated neuronal survival have not yet been established. In one of the earliest experiments, GRN was identified to abrogate the requirement for insulin-like growth factor receptor 1 (IGFR1) for growth in vitro by promoting cell proliferation in mouse embryonic fibroblasts derived from IGFR1 knockout mice (Xu et al. 1998). These cells were otherwise unable to proliferate in response to not only IGF-1 but also other growth factors such as epidermal growth factor and platelet-derived growth factor that are necessary to fully progress through the cell cycle (Sell et al. 1994). Overexpression of GRN or treatment with recombinant GRN was also shown to activate phosphatidylinositol 3-kinase (PI3K) and mitogen-activated protein kinase (MAPK) pathways in non-neuronal primary cells and cancer cell lines (ZanoccoMarani et al. 1999; Monami et al. 2006). This was recently confirmed on non-neuronal cells derived from $\mathrm{GRN}^{-1-}$ mice that allows studies of GRN signaling pathways without the low-level continuous stimulation otherwise present in cells where GRN alleles are intact (Kleinberger et al. 2010). However, in neuronal cells, GRN signaling pathways were shown to be subtly different from those known for nonneuronal cells with preferential involvement of PI3K/Akt signaling pathways and with baseline phospho-Akt levels reduced in $\mathrm{GRN}^{-/-}$neurons (Kleinberger et al. 2010). In other cells such as bone marrow-derived macrophages, GRN deficiency led to lipopolysaccharide-stimulated upregulation of proinflammatory chemokines and cytokines such as monocyte chemoattractant protein-1, CXCL1, IL-6, IL-12, and, importantly, TNF- $\alpha$, as well as downregualtion of IL-10 (Yin et al. 2010). These data suggested that GRN is involved in quite disparate pathways.

The receptors of GRN have been equally inexplicable. Earliest data from competitive binding experiments indicated a long list of known growth factors and cytokines that were unable to displace radiolabeled GRN binding to its putative receptor, suggesting that the receptor for GRN might not be a known tyrosine kinase receptor (Culouscou et al. 1993). Two recent studies have suggested separate putative GRN receptors. Utilizing a cleverly designed ligand-binding assay and expression cloning screening in COS-7 cells, the C terminus portion of GRN was shown to bind to sortilin ( $\mathrm{Hu}$ et al. 2010). Sortilin is a single-pass type I transmembrane protein of the Vps10 family that is localized to the cell 
surface and to secretory and endocytic compartments (Willnow et al. 2008). Upon binding to GRN, sortilin-GRN complex is rapidly endocytosed and delivered to lysosomes thereby regulating the extracellular levels of GRN. Mice lacking sortilin show up to fivefold elevation in brain and serum GRN levels (Hu et al. 2010). Sortilin in complex with p75NTR also performs proneurotrophin apoptotic signaling, but GRN binding to sortilin does not seem to be modulated by p75NTR (Hu et al. 2010). While the precise signaling mechanisms involved in GRN-sortilin pathway are unknown, these studies already indicate that sortilin is yet another modulator of GRN levels in brain.

In another study, in a yeast two-hybrid cDNA library screening, GRN was recognized to bind to tumor necrosis factor receptor (TNFR) (Tang et al. 2011). The best known TNFR ligand, TNF- $\alpha$, is a trimeric protein encoded within the major histocompatibility complex and shares a number of common functions with GRN such as their major production by cells of macrophage lineage, pleiotropic inflammatory and growth modulatory functions, and involvement in wound healing and cancer. GRN exerts its anti-inflammatory effects through inhibition of TNF-TNFR-mediated NF-KB and MAPK signaling by competitively binding to TNFR especially TNFR-2 present in bone marrow-derived macrophages (Tang et al. 2011). It is possible that growth modulatory properties of GRN are also due to negative regulation of TNF$\alpha$ signaling with both growth-enhancing and growthinhibitory properties depending upon the cellular context. Such binding can also explain other phenotypes of FTLD. For instance, TNF- $\alpha$ with a biphasic diurnal pattern contributes in regulating the body's circadian rhythm and modulating sleep (Young et al. 1995), and significant circadian rhythm problems and sleep disturbances are described in FTLD patients (Anderson et al. 2009). Ongoing studies will show what all TNFR-GRN interactions occur in frontocortical brain regions, but it is very likely that in future, more multiligand cell-surface receptors for GRN will be identified providing us with a more global picture of GRN cell-signaling pathways that are abrogated in FTLD-TDP.

\section{TDP-43 Pathology: A Cause or Consequence of Neurodegeneration?}

An important research question for studies involving GRN haploinsufficiency-led neurodegeneration and other TDP-43 proteinopathies is whether the mislocalization, cleavage, or abnormal aggregation of TDP-43 is a cause or consequence of the disease pathogenesis. This is because, as discussed earlier, TDP-43 pathology is also present in other neurodegenerative disorders (Dickson 2008). TDP-43 pathology is absent in ALS cases due to SOD1 mutations (Mackenzie et al. 2007); however, mutant SOD1 mouse model and other ALS mouse models such as Wobbler mice (due to mutant Vps54 gene) show upregulation, mislocalization, and accumulation of TDP-43 in brain (Shan et al. 2009; Dennis and Citron 2009).

The fact that missense mutations in TDP-43 lead to ALS (Sreedharan et al. 2008; Van Deerlin et al. 2008; Kabashi et al. 2008) and ALS-FTLD (Benajiba et al. 2009) is a very important argument in the favor of primary perturbations in TDP-43 leading to disease on its own and a testimony of a sufficiently upstream and central mechanism in FTLD-TDP. In vitro studies on select ALS mutants have also shown their abnormal mislocalization, aggregation, increased toxicity, and sequestration of physiological TDP-43 (Winton et al. 2008; Johnson et al. 2008; Barmada et al. 2010). Thus, it remains unknown what is most central to TDP-43 pathology: a toxic gain of one or more toxic properties of TDP-43 accumulation or a loss of normal physiological TDP-43 function.

\section{TDP-43 Pathology: A Loss-of-Function Mechanism?}

One of the first suggestions of a possible loss of TDP-43 function was based on observations that cells harboring TDP43 cytoplasmic or nuclear inclusions in ALS and FTLD-U patients lacked the diffuse nuclear TDP-43 staining, suggested to be due to sequestration of the physiological TDP-43 within the cellular aggregates. While the precise mechanism of nuclear depletion of TDP-43 remains unstudied, the knowledge that TDP-43 is crucial in processing of so many RNA targets makes it unlikely that loss of nuclear TDP-43 would be without consequences on cell function and viability. A likely loss of function in RNA processing as a key molecular event in ALS and related disorders is also supported by identification of dominant missense mutations in ALS patients in the gene encoding FUS/TLS with which TDP-43 shares striking structural and functional similarities (FUsed in Sarcoma/ Translocated in Liposarcoma) (Kwiatkowski et al. 2009; Vance et al. 2009). Accordingly, loss of TDP-43 in experimental studies is shown to be toxic to in vivo and cultured neurons. For instance, knockout/knockdown of Drosophila TDP-43 results in locomotive behavior and reduced life span accompanied by disturbed neuromuscular junctions and decreased dendritic branching (Feiguin et al. 2009; Lu et al. 2009). Similarly, homozygous disruption of murine TDP-43 (mTDP-43) is shown to embryonically lethal perhaps because of defective outgrowth of the inner cell mass prior to implantation (Wu et al. 2010; Sephton et al. 2010; Kraemer et al. 2010). Heterozygous adult mice show subtle motor disturbance and muscle weakness (Kraemer et al. 2010).

Surprisingly, however, the phenotype resulting from TDP-43 knockout is mild compared to the phenotype observed for transgenic mice overexpressing human TDP-43 (hTDP-43) showing a cell-autonomous ALS/FTLD-like neurodegeneration with ubiquitin ${ }^{+}$, and also occasionally TDP- 
$43^{+}$, accumulations (Kumar-Singh et al. 2009; Wegorzewska et al. 2009; Wils et al. 2010). Sequestration of endogenous mTDP-43 into these cellular aggregates does not occur in transgenic hTDP-43 mouse models; however, these models instead show a transgene dose-dependent decrease in the endogenous mTDP-43 (Kumar-Singh et al. 2009; Xu et al. 2010; Igaz et al. 2011). This is proposed to be due to autoregulation, an important internal adaptive mechanism for several physiological processes with many proteins sensitive for gene dosage being autoregulated. Transgenic overexpression of sufficiently homologous genes has also been shown to lead to downregulation of endogenous transcripts/proteins as observed with a high transgenic presenilin expression causing a near shutdown of endogenous presenilin synthesis (Thinakaran et al. 1997; Kumar-Singh et al. 2006). Similarly, TDP-43 with crucial dose-dependent functions is also autoregulated in part by directly binding and enhancing splicing of an intron in the $3^{\prime}$ UTR of its own transcript, thereby triggering nonsense-mediated RNA degradation (Ayala et al. 2011; Polymenidou et al. 2011).

If indeed loss of endogenous mTDP-43 rather than an increase in transgenically expressed hTDP-43 is pathogenic in these mouse models, we need to seek answers to three relevant questions. One, how much is the reduction of endogenous TDP-43? In Thy- 1 driven wild-type (Wt) hTDP-43 homozygous TAR4/4 mice, $26 \%$ reduction of mTDP-43 was observed by Q-RT-PCR in whole brain, when normalized to Actb housekeeping gene (Kumar-Singh et al. 2009). In contrast to neuron-specific Thy 1 promoter, a more ubiquitous TDP-43 expression by PrP promoter led to $\sim 70 \%$ decrease in mTDP-43 in the homozygous line (Xu et al. 2010), and a similar decrease in forebrain of mice was also observed in hTDP-43 overexpressing mice under Camk2a conditional promoter (Igaz et al. 2011). While absolute reduction of endogenous mTDP-43 is dependent on levels of exogenous hTDP-43, the expression pattern of the promoter in context of how the analysis is performed also influences the readout. For instance, neuron-specific Thy-1 lines show less suppression of endogenous transcripts on a total brain analysis when compared to the PrP lines where the expression is in both neurons and glial cells. An added problem is also in choosing appropriate housekeeping genes due to the extensive list of RNA that TDP-43 targets. Single cell protein analysis such as immunohistochemistry can yield interesting results, but these are complicated by the fact that endogenous TDP-43 expression varies between cells and, for reasons not yet known, a near-complete absence of TDP-43 immunoreactivity is also observed in a proportion of healthy appearing neurons and glial cells (Fig. 2c, d).

If we can assume that TDP-43 reduction indeed exceeds $50 \%$, levels at which it can be causing considerable loss of function, a next logical question would be how homologous are hTDP-43 and mTDP-43 as the total TDP-43 levels are elevated in these models? Interestingly, mTDP-43 is $96 \%$ homologous to hTDP-43, and hTDP-43 completely rescues a loss-of-function phenotype in flies with which it shows only $46 \%$ homology (Feiguin et al. 2009). Finally, if reduction of mTDP-43 is pathogenic on its own, then overexpression of autologous TDP-43 should not be as toxic. Interestingly, mice overexpressing mTDP-43 have been made (Tsai et al. 2010) that show a remarkably similar phenotype to hTDP-43-expressing mice (Wils et al. 2010). These data thus suggest that a loss-of-function mechanism at least with the phenotype observed in the TDP-43 overexpressing mice is less likely.

Nevertheless, as discussed earlier, it is highly unlikely that sequestration of physiological TDP-43 within the aggregates or the missense mutations within TDP-43 does not cause any loss of function of the many diverse and critical functions that TDP-43 executes (Buratti and Baralle 2008; Lagier-Tourenne et al. 2010). It is possible that loss of function caused by specific TDP-43 mutations is mechanistically divergent. For instance, ALS-associated R361S, but not D169G, have been shown to alter formation of stress granules that are important for RNA stability during stress (McDonald et al. 2011).

\section{TDP-43 in Neurodegeneration: A Gain of Function?}

Genetically, a gain-of-aberrant-function mechanism is suggested when both overexpression of the Wt protein and dominant missense mutant protein lead to the same phenotype. This has been the case with many neurodegenerative disorders with defects in causative genes such as $A P P$ in $\mathrm{AD}$ or SNCA in Parkinson's disease (PD) (Hardy and Selkoe 2002). While gross gene duplications have not been shown for TARDBP, polymorphisms within the 3' UTR region have been identified that are suggested to increase TDP-43 levels (Gitcho et al. 2009a). Moreover, gene expression studies have shown an $\sim 1.5$-fold increase in TARDBP mRNA levels in both FTLD-U and FTLD-MND cases compared to controls (Mishra et al. 2007), and preliminary Q-RT-PCR analysis on limited $G R N$ causal mutation carriers also showed slightly higher TARDBP levels (Chen-Plotkin et al. 2008). In limited clinical studies, higher TDP-43 protein levels were also observed in pathological samples of ALS (Kabashi et al. 2008).

While further genetic and clinical proof of TDP-43 dosage in ALS/FTLD is awaited, animal models of TDP-43 have been constructed that also show a high degree of TDP43 dose-related toxicity. For instance, expression of $\mathrm{Wt}$ hTDP-43 in Drosophila causes impaired locomotor activity (Li et al. 2010), as well as paralysis and reduced life span (Hanson et al. 2010). Similarly, as discussed above, over- 
expression of Wt hTDP-43 in mice causes a very rapidly progressive paralysis reminiscent of human ALS in a dosedependent manner (Wils et al. 2010; Tsai et al. 2010). Overexpression of Wt TDP-43 in neurons in vitro (Barmada et al. 2010) or in vivo (Tatom et al. 2009) also leads to cell death independently of mutation. A TDP-43 dose-dependent toxicity leading to an expected phenotype suggests a gain-offunction mechanism in TDP-43-led proteinopathies.

Conversely, the molecular mechanisms by which dominant missense mutations in TARDBP are pathogenic is more complex. Most of the TDP-43 mutations clustered in the glycine-rich C-terminal domain of the protein are missense mutations (Fig. 1b) with the exception of a rare truncating mutation (Sreedharan et al. 2008; Van Deerlin et al. 2008; Kabashi et al. 2008; Benajiba et al. 2009). Surely, the mutations could cause an altered protein binding or specificity; however, these could also suggest a possible gain-of-toxic property for mutant TDP-43. Studies of proteinopathies in other neurodegenerative diseases like $\mathrm{AD}$ $(\mathrm{A} \beta)$, FTLD- $\tau$ tau (tau), and PD ( $\alpha$-synuclein) are again instructive. For example in AD, APP is abnormally processed by mutations near the secretases that lead to increased production of fibrillogenic $A \beta 42$ or, when the mutations are within the $A \beta$ domain, alter the kinetics of $A \beta$ aggregation (reviewed in Van Broeck et al. 2007). While the molecular basis for TDP-43 proteolysis and the effect of these missense mutations on TDP-43 proteolysis are unknown, the $\sim 25-\mathrm{kDa}$ TDP-43 CTFs were recovered in detergent-insoluble urea fractions of affected brain regions of FTLD-TDP and ALS patients (Neumann et al. 2006; Arai et al. 2006). Overexpression of TDP-43 CTFs of different lengths in cultured cells produces cytoplasmic aggregates that are ubiquitinated and phosphorylated, thus recapitulating the biochemical properties of pathological TDP-43 inclusions (Igaz et al. 2009; Dormann et al. 2009; Nonaka et al. 2009; Zhang et al. 2009). In TDP-43 animal models, $\sim 25-\mathrm{kDa}$ CTFs are also produced and correlate with disease progression (Wegorzewska et al. 2009; Wils et al. 2010). Interestingly, TDP-43 and its CTFs are largely localized to neuronal nuclei in these models (Wils et al. 2010) and fit well with a similar nuclear localization of ectopically expressed TDP-43 in Drosophila (Hanson et al. 2010). These data suggest that increased Wt TDP-43 dosage could be pathogenic via a nuclear mechanism (Wils et al. 2010).

Although CTFs could be toxic, full-length (FL) TDP-43 is also inherently aggregation-prone, and ALS-linked mutations further increase the aggregating propensity of the protein (Johnson et al. 2009; Dormann et al. 2009). In both Wt and mutant TDP-43 mouse models, the FL TDP-43 was shown to be overrepresented compared to $\sim 25-\mathrm{kDa}$ CTF (Wils et al. 2010; Wegorzewska et al. 2009). Some form of tissue modulation towards the precise TDP-43 being deposited is also suggested by preferential recovery of FL TDP-43 from spinal cord, while TDP-43 CTFs were more common in cortical brain regions (Igaz et al. 2008).

Equally interesting is the evidence that questions an early role of TDP-43 aggregates in TDP-43 led toxicity. It is clear from TDP-43 animal model studies that only in high transgene-expressing lines were a minority of ubiquitin ${ }^{+}$ aggregates also TDP-43 ${ }^{+}$(Wils et al. 2010; Wegorzewska et al. 2009; Xu et al. 2010); however, lower expressing lines (Wils et al. 2010; Igaz et al. 2011) did not have aggregates and yet showed neurodegeneration. Moreover, in the high expressing TDP-43 Thy-1 mice, FL TDP-43 or the $\sim 25-\mathrm{kDa}$ CTF was also recovered in the more soluble TBS-X fraction in serial solubilization assays (Wils et al. 2010) and corroborated a recent study where de novo cleaved CTFs within nucleus were cleared without aggregation (Pesiridis et al. 2011). These data strongly support the idea that cellular aggregate formation might not be a prerequisite for the neurodegeneration observed in TDP-43 proteinopathies although they contribute to disease progression as has been suggested for mutant SOD1 (Karch et al. 2009). Notwithstanding the precise loss- or gain-of-function mechanism, these data all suggest that perturbations in TDP-43 dose or structure are sufficient to cause cell-associated toxicity.

\section{The Link Between GRN Loss and TDP-43 Pathology}

\section{Role of Caspases}

The first proposal for a link between GRN haploinsufficiency and TDP-43 pathology was suggested to be mediated via caspases (Zhang et al. 2007). Caspase-mediated apoptosis is recognized as a characteristic feature of FTLD (Su et al. 2000), and in prior studies, TDP-43 was identified as a substrate for Fas-induced apoptosis (Van Damme et al. 2005). Also, consistent with withdrawal of the fetal calf serum or major trophic factors causing a strong apoptotic signal, sequestration of GRN by GRN-specific antibodies in the select GRN-dependent cancer cell lines has been shown to induce apoptosis (Kamrava et al. 2005; He et al. 2002). Recently, Zhang et al. (2007) while silencing GRN in two immortalized cell lines by a $G R N$-specific siRNA noticed a dramatic caspase activation and caspase-mediated TDP-43 fragmentation into $\sim 25-$ and $\sim 35-\mathrm{kDa}$ CTFs. However, three subsequent studies did not confirm these data on similar immortalized cell lines utilizing a battery of GRN-specific siRNAs (Shankaran et al. 2008; Dormann et al. 2009; Kleinberger et al. 2010). One study also utilized fibroblasts derived from $\mathrm{Grn}^{-/}$embryos to circumvent the problem of typical $\sim 80 \%$ of cells being targeted in siRNA experiments but saw no effect on caspase activation/apoptosis or TDP-43 fragmentation (Kleinberger et al. 2010). GRN deficiency, however, caused an expected anti-proliferative effect in these 
models (Kleinberger et al. 2010), suggesting that although GRN significantly impacts on cell proliferation, it is not sufficient to cause appreciably increased apoptosis in proliferating cells. These data are consistent with the premise that transient cell growth arrest in certain situations is protective against apoptosis.

Studies on in vivo neurons have also not shown significant activation of caspases, appreciable apoptosis, or TDP-43 pathology in zebrafish model and GRN knockout $\left(\mathrm{Grn}^{-/}\right)$mouse models (Shankaran et al. 2008; Ahmed et al. 2010; Wils et al., submitted). Absence of any signs of increased apoptosis could be due to increased clearance of apoptotic cells by increased macrophage activity as has been shown to occur in the development of Caenorhabditis elegans (Kao et al. 2011). However, in mixed embryonic $\mathrm{Grn}^{-/-}$cortical cultures that also contain microglia, an increased caspase activity accompanied decreased cellular viability and subtle increase in $\sim 25-\mathrm{kDa}$ CTFs; however, these TDP-43 fragments did not become insoluble or abnormally phosphorylated (Kleinberger et al. 2010). Caspase activation and $\sim 25-\mathrm{kDa}$ CTFs have also been observed in acute ischemic stroke model, but again these TDP-43 fragments did not progress to abnormal phosphorylation or insolubilization (Kanazawa et al. 2011). Lastly, pathological TDP-43 CTF purified from FTLD-TDP brains are shown to extend from amino-acid Arg-208, while the predicted caspase-derived $\sim 25-\mathrm{kDa}$ CTFs are shorter, beginning at Val-220. These data suggest that while caspase-derived TDP-43 CTFs might not be the initiating link between GRN and TDP-43, some caspase-mediated TDP-43 fragmentation could be expected in the course of the disease contributing to the disease progression.

\section{Role of Subtle Cell Stress}

Accumulating data suggest that GRN loss might cause increased cellular stress, that, on its own, can also lead to cellular dysfunction and initiate TDP-43 pathology. GRN mediates stress response caused by microenvironmental stressors such as hypoxia or mild acidosis by increasing GRN expression from cultured fibroblasts that do not express GRN in vivo (Guerra et al. 2007). Treatment with GRN in physiological concentrations also protected cells from apoptosis induced by extreme acidosis (Guerra et al. 2007). Moreover, while GRN expression is upregulated in microglia in a variety of neurodegenerative disorders (Daniel et al. 2000; Baker and Manuelidis 2003), increased GRN expression is also observed within neurons (Malaspina et al. 2001; Irwin et al. 2008). Interestingly, miR-107, which was previously implicated in $\mathrm{AD}$ pathogenesis, modulates GRN levels (Wang et al. 2010), and a significant upregulation of Grn was also shown in $\mathrm{AD}$ mouse models by transcriptomic analyses (Pereson et al. 2009). In these models, GRN reactivity was mostly observed within microglia; however, neurons also showed increased GRN expression, especially those in the vicinity of dense-core plaques known to be stressful to surrounding neurons (Pereson et al. 2009). Moreover, GRN secreted by microglia has been proposed to be internalized by sortilin mostly localized on neurons, suggesting that GRN upregulation could partly be involved in the neuronal stress response (Hu et al. 2010). In support of these data, $\mathrm{Grn}^{-/}$mouse models show signs of increased brain aging such as accelerated neuronal lipofuscinosis and ubiquitination (Ahmed et al. 2010; Wils et al. 2008). Moreover, although no increased apoptosis or caspase reactivity was observed in these mouse models (Ahmed et al. 2010; Wils et al. 2008), the finding that $\mathrm{Grn}^{-/}$ neurons, when extruded to in vitro cultures thereby challenging them with stress associated with such a process, show increased apoptosis and are rescued by exogenous treatment of synthetic GRN, is interesting (Kleinberger et al. 2010). Taken together, these data suggest that GRN is a trophic factor essential for neuronal survival during stressful conditions and plays a key role in maintaining neuronal function during aging (Ahmed et al. 2010; Wils et al. 2008).

$\mathrm{Grn}^{-1-}$ mouse models also show abnormalities in ubiquitin-proteasome (Ub-Pr) and lysosomal pathways, a characteristic feature of FTLD-TDP (Lehman 2009; Kumar-Singh and Van Broeckhoven 2007). Other genes involved with FTLD-TDP also have a direct role in Ub-Pr and lysosomal functions. For instance, almost all cellular activities of VCP are directly or indirectly regulated by the $\mathrm{Ub}-\mathrm{Pr}$ system, and FTLD-TDP-associated mutant VCP leads to endoplasmic stress and decreased proteasome activity (Gitcho et al. 2009b). Similarly, yeast CHMP2B is involved in transmembrane protein sorting and trafficking along late endosomes to multivesicular bodies and lysosomes. Dysfunction of these components results in the inability of the multivesicular bodies to internalize membrane-bound cargo and results in poor protein turnover (Babst et al. 2002). The putative GRNreceptor sortilin is also suggested to play an important role in lysosomal degradation and turnover of many proteins, including perhaps TDP-43 (Hu et al. 2010).

While GRN deficiency causes cell stress or increases susceptibility to cellular stressors due to poor protein turnover, cellular stress alone was also shown to alter TDP-43 solubility. Staurosporine-induced apoptotic stress in HeLa cells has been shown to cause formation of insoluble aggregates consisting of TDP-43 FL and CTFs (Dormann et al. 2009). Similarly, proteasomal blocking in cultured neurons by MG132 also showed a decreased solubility of FL TDP-43 and an increased TDP-43 cytoplasmic accumulation, which was consistently higher in $\mathrm{GRN}^{-/}$ neurons (Kleinberger et al. 2010). Interestingly, overexpression of TDP-43 or its fragments at physiological levels has not been shown to aggregate unless cells encounter another 
"hit" such as those caused by cell stressors (Pesiridis et al. 2011). Recent data also suggest that TDP-43 itself might have an important role in assembly and maintenance of stress granules following oxidative stress (McDonald et al. 2011). Stress granules are aggregations of proteins and RNAs that appear when the cell is under stress and helps to protect RNAs from harmful conditions. Whether this activity is tweaked by GRN remains to be shown.

\section{Conclusions and Future Directions}

In conclusion, the current evidence strongly implicates TDP43 as a key molecule in the pathogenic cascade of FTLD/ALS. It is also clear that causal mutations in GRN are loss-offunction mutations. Elucidation of the GRN function(s) that are most central to frontotemporal neurons is an important prerequisite in deciphering underlying disease mechanism and developing targeted therapies. The current knowledge suggests that GRN deficiency, although not sufficient to cause apoptosis in vivo, increases susceptibility to cellular stressors, and in combination with other disease modulators, these perturbations could cause TDP-43 to mislocalize and become insoluble. Learning from research carried out for other neurodegenerative diseases, it is very likely that TDP-43 toxicity involves both a loss of its multiple functions on RNA processing as well as a toxic gain of function in disparate but convergent pathways. TDP-43-mediated gain of toxic function could initially involve a malfunction due to the soluble forms of TDP-43, and perhaps in later part of the disease, TDP-43-containing aggregates might also contribute by increasing cellular stress generally associated with accumulating misfolded proteins. Recent identification of two putative GRN receptors will also help to elucidate how GRN is regulated by sortilin and how some of the functions of GRN, likely the inflammatory ones, could be mediated by its interaction with TNF- $\alpha$. While involvement of these receptors in disease pathogenesis should be thoroughly investigated, search for other cell-surface proteins, with which GRN or its grn-peptides interact with intermediate-to-high affinities, should also be prioritized to provide us with a more complete picture of disease pathogenesis.

Acknowledgments The author thanks the Born-Bunge Tissue Bank for archival photomicrographs of FTLD brains. Funding from Research Funds of the University of Antwerp and from Research Foundation-Flanders (FWO-F) is acknowledged.

Open Access This article is distributed under the terms of the Creative Commons Attribution Noncommercial License which permits any noncommercial use, distribution, and reproduction in any medium, provided the original author(s) and source are credited.

\section{References}

Ahmed Z, Mackenzie IR, Hutton ML, Dickson DW (2007) Progranulin in frontotemporal lobar degeneration and neuroinflammation. J Neuroinflammation 4:7

Ahmed Z, Sheng H, Xu YF, Lin WL, Innes AE, Gass J, Yu X, Wuertzer CA, Hou H, Chiba S, Yamanouchi K, Leissring M, Petrucelli L, Nishihara M, Hutton ML, McGowan E, Dickson DW, Lewis J (2010) Accelerated lipofuscinosis and ubiquitination in granulin knockout mice suggest a role for progranulin in successful aging. Am J Pathol 177:311-324

Anderson KN, Hatfield C, Kipps C, Hastings M, Hodges JR (2009) Disrupted sleep and circadian patterns in frontotemporal dementia. Eur J Neurol 16:317-323

Arai T, Hasegawa M, Akiyama H, Ikeda K, Nonaka T, Mori H, Mann D, Tsuchiya K, Yoshida M, Hashizume Y, Oda T (2006) TDP-43 is a component of ubiquitin-positive tau-negative inclusions in frontotemporal lobar degeneration and amyotrophic lateral sclerosis. Biochem Biophys Res Commun 351:602-611

Ayala YM, Zago P, D’Ambrogio A, Xu YF, Petrucelli L, Buratti E, Baralle FE (2008) Structural determinants of the cellular localization and shuttling of TDP-43. J Cell Sci 121:3778-3785

Zhu J, Nathan C, Jin W, Sim D, Ashcroft GS, Wahl SM, Lacomis L, Erdjument-Bromage H, Tempst P, Wright CD, Ding A (2002) Conversion of proepithelin to epithelins: roles of SLPI and elastase in host defense and wound repair. Cell 111:867-878

Ayala YM, De CL, Avendano-Vazquez SE, Dhir A, Romano M, D'Ambrogio A, Tollervey J, Ule J, Baralle M, Buratti E, Baralle FE (2011) TDP-43 regulates its mRNA levels through a negative feedback loop. EMBO J 30:277-288

Baba T, Hoff HB III, Nemoto H, Lee H, Orth J, Arai Y, Gerton GL (1993) Acrogranin, an acrosomal cysteine-rich glycoprotein, is the precursor of the growth-modulating peptides, granulins, and epithelins, and is expressed in somatic as well as male germ cells. Mol Reprod Dev 34:233-243

Babst M, Katzmann DJ, Estepa-Sabal EJ, Meerloo T, Emr SD (2002) Escrt-III: an endosome-associated heterooligomeric protein complex required for mvb sorting. Dev Cell 3:271-282

Baker CA, Manuelidis L (2003) Unique inflammatory RNA profiles of microglia in Creutzfeldt-Jakob disease. Proc Natl Acad Sci USA 100:675-679

Baker M, Mackenzie IR, Pickering-Brown SM, Gass J, Rademakers R, Lindholm C, Snowden J, Adamson J, Sadovnick AD, Rollinson S, Cannon A, Dwosh E, Neary D, Melquist S, Richardson A, Dickson D, Berger Z, Eriksen J, Robinson T, Zehr C, Dickey CA, Crook R, McGowan E, Mann D, Boeve B, Feldman H, Hutton M (2006) Mutations in progranulin cause tau-negative frontotemporal dementia linked to chromosome 17. Nature 442:916-919

Barmada SJ, Skibinski G, Korb E, Rao EJ, Wu JY, Finkbeiner S (2010) Cytoplasmic mislocalization of TDP-43 is toxic to neurons and enhanced by a mutation associated with familial amyotrophic lateral sclerosis. J Neurosci 30:639-649

Bartel DP (2009) MicroRNAs: target recognition and regulatory functions. Cell 136:215-233

Benajiba L, Le Ber I, Camuzat A, Lacoste M, Thomas-Anterion C, Couratier P, Legallic S, Salachas F, Hannequin D, Decousus M, Lacomblez L, Guedj E, Golfier V, Camu W, Dubois B, Campion $\mathrm{D}$, Meininger V, Brice A (2009) TARDBP mutations in motoneuron disease with frontotemporal lobar degeneration. Ann Neurol 65:470-473

Brun A, Englund B, Gustafson L, Passant U, Mann DMA, Neary D, Snowden JS (1994) Clinical and neuropathological criteria for frontotemporal dementia. J Neurol Neurosurg Psychiatry 57:416-418

Buratti E, Baralle FE (2001) Characterization and functional implications of the RNA binding properties of nuclear factor TDP-43, a 
novel splicing regulator of CFTR exon 9. J Biol Chem 276:36337-36343

Buratti E, Baralle FE (2008) Multiple roles of TDP-43 in gene expression, splicing regulation, and human disease. Front Biosci $13: 867-878$

Carrasquillo MM, Nicholson AM, Finch N, Gibbs JR, Baker M, Rutherford NJ, Hunter TA, Dejesus-Hernandez M, Bisceglio GD, Mackenzie IR, Singleton A, Cookson MR, Crook JE, Dillman A, Hernandez D, Petersen RC, Graff-Radford NR, Younkin SG, Rademakers R (2010) Genome-wide screen identifies rs646776 near sortilin as a regulator of progranulin levels in human plasma. Am J Hum Genet 87:890-897

Chen-Plotkin AS, Geser F, Plotkin JB, Clark CM, Kwong LK, Yuan W, Grossman M, Van Deerlin VM, Trojanowski JQ, Lee VM (2008) Variations in the progranulin gene affect global gene expression in frontotemporal lobar degeneration. Hum Mol Genet 17:1349-1362

Cruts M, Gijselinck I, van der Zee J, Engelborghs S, Wils H, Pirici D, Rademakers R, Vandenberghe R, Dermaut B, Martin JJ, van Duijn C, Peeters K, Sciot R, Santens P, De Pooter T, Mattheijssens M, Van den Broeck M, Cuijt I, Vennekens K, De Deyn PP, Kumar-Singh S, Van Broeckhoven C (2006) Null mutations in progranulin cause ubiquitin-positive frontotemporal dementia linked to chromosome 17q21. Nature 442:920-924

Culouscou JM, Carlton GW, Shoyab M (1993) Biochemical analysis of the epithelin receptor. J Biol Chem 268:10458-10462

Daniel R, He Z, Carmichael KP, Halper J, Bateman A (2000) Cellular localization of gene expression for progranulin. J Histochem Cytochem 48:999-1009

Dennis JS, Citron BA (2009) Wobbler mice modeling motor neuron disease display elevated transactive response DNA binding protein. Neuroscience 158:745-750

Dickson DW (2008) TDP-43 immunoreactivity in neurodegenerative disorders: disease versus mechanism specificity. Acta Neuropathol 115:147-149

Dickson DW, Baker M, Rademakers R (2010) Common variant in GRN is a genetic risk factor for hippocampal sclerosis in the elderly. Neurodegener Dis 7:170-174

Dormann D, Capell A, Carlson AM, Shankaran SS, Rodde R, Neumann M, Kremmer E, Matsuwaki T, Yamanouchi K, Nishihara M, Haass C (2009) Proteolytic processing of TAR DNA binding protein- 43 by caspases produces C-terminal fragments with disease defining properties independent of progranulin. $\mathrm{J}$ Neurochem 110:1082-1094

Feiguin F, Godena VK, Romano G, D'Ambrogio A, Klima R, Baralle FE (2009) Depletion of TDP-43 affects Drosophila motoneurons terminal synapsis and locomotive behavior. FEBS Lett 583:1586-1592

Forman MS, Mackenzie IR, Cairns NJ, Swanson E, Boyer PJ, Drachman DA, Jhaveri BS, Karlawish JH, Pestronk A, Smith TW, Tu PH, Watts GD, Markesbery WR, Smith CD, Kimonis VE (2006) Novel ubiquitin neuropathology in frontotemporal dementia with valosin-containing protein gene mutations. J Neuropathol Exp Neurol 65:571-581

Galimberti D, Fenoglio C, Cortini F, Serpente M, Venturelli E, Villa C, Clerici F, Marcone A, Benussi L, Ghidoni R, Gallone S, Scalabrini D, Restelli I, Boneschi FM, Cappa S, Binetti G, Mariani C, Rainero I, Giordana MT, Bresolin N, Scarpini E (2010) GRN variability contributes to sporadic frontotemporal lobar degeneration. J Alzheimers Dis 19:171-177

Gass J, Cannon A, Mackenzie IR, Boeve B, Baker M, Adamson J, Crook R, Melquist S, Kuntz K, Petersen R, Josephs K, PickeringBrown SM, Graff-Radford N, Uitti R, Dickson D, Wszolek Z, Gonzalez J, Beach TG, Bigio E, Johnson N, Weintraub S, Mesulam M, White CL III, Woodruff B, Caselli R, Hsiung GY, Feldman H, Knopman D, Hutton M, Rademakers R (2006) Mutations in progranulin are a major cause of ubiquitin-positive frontotemporal lobar degeneration. Hum Mol Genet 15:2988-3001
Gijselinck I, van der Zee J, Engelborghs S, Goossens D, Peeters K, Mattheijssens M, Corsmit E, Del-Favero J, De Deyn PP, Van BC, Cruts M (2008) Progranulin locus deletion in frontotemporal dementia. Hum Mutat 29:53-58

Gitcho MA, Bigio EH, Mishra M, Johnson N, Weintraub S, Mesulam M, Rademakers R, Chakraverty S, Cruchaga C, Morris JC, Goate AM, Cairns NJ (2009a) TARDBP 3'-UTR variant in autopsyconfirmed frontotemporal lobar degeneration with TDP-43 proteinopathy. Acta Neuropathol 118:633-645

Gitcho MA, Strider J, Carter D, Taylor-Reinwald L, Forman MS, Goate AM, Cairns NJ (2009b) VCP mutations causing frontotemporal lobar degeneration disrupt localization of TDP-43 and induce cell death. J Biol Chem 284:12384-12398

Guerra RR, Kriazhev L, Hernandez-Blazquez FJ, Bateman A (2007) Progranulin is a stress-response factor in fibroblasts subjected to hypoxia and acidosis. Growth Factors 25:280-285

Hanson KA, Kim SH, Wassarman DA, Tibbetts RS (2010) Ubiquilin modifies TDP-43 toxicity in a Drosophila model of amyotrophic lateral sclerosis (ALS). J Biol Chem 285:11068-11072

Hardy J, Selkoe DJ (2002) The amyloid hypothesis of Alzheimer's disease: progress and problems on the road to therapeutics. Science 297:353-356

He Z, Bateman A (2003) Progranulin (granulin-epithelin precursor, PC-cell-derived growth factor, acrogranin) mediates tissue repair and tumorigenesis. J Mol Med 81:600-612

He ZH, Ismail A, Kriazhev L, Sadvakassova G, Bateman A (2002) Progranulin (PC-cell-derived growth factor/acrogranin) regulates invasion and cell survival. Cancer Res 62:5590-5596

Hodges JR, Davies RR, Xuereb JH, Casey B, Broe M, Bak TH, Kril JJ, Halliday GM (2004) Clinicopathological correlates in frontotemporal dementia. Ann Neurol 56:399-406

Hu F, Padukkavidana T, Vaegter CB, Brady OA, Zheng Y, Mackenzie IR, Feldman HH, Nykjaer A, Strittmatter SM (2010) Sortilinmediated endocytosis determines levels of the frontotemporal dementia protein, progranulin. Neuron 68:654-667

Hutton M, Lendon CL, Rizzu P, Baker M, Froelich S, Houlden H, Pickering-Brown S, Chakraverty S, Isaacs A, Grover A, Hackett J, Adamson J, Lincoln S, Dickson D, Davies P, Petersen RC, Stevens M, de Graaff E, Wauters E, van Baren J, Hillebrand M, Joosse M, Kwon JM, Nowotny P, Heutink P (1998) Association of missense and $5^{\prime}$-splice-site mutations in tau with the inherited dementia FTDP-17. Nature 393:702-705

Igaz LM, Kwong LK, Xu Y, Truax AC, Uryu K, Neumann M, Clark CM, Elman LB, Miller BL, Grossman M, McCluskey LF, Trojanowski JQ, Lee VM (2008) Enrichment of C-terminal fragments in TAR DNA-binding protein-43 cytoplasmic inclusions in brain but not in spinal cord of frontotemporal lobar degeneration and amyotrophic lateral sclerosis. Am J Pathol 173:182-194

Igaz LM, Kwong LK, Chen-Plotkin A, Winton MJ, Unger TL, Xu Y, Neumann M, Trojanowski JQ, Lee VM (2009) Expression Of TDP-43 C-terminal fragments in vitro recapitulates pathological features of TDP-43 proteinopathies. J Biol Chem 284:8516-8524

Igaz LM, Kwong LK, Lee EB, Chen-Plotkin A, Swanson E, Unger T, Malunda J, Xu Y, Winton MJ, Trojanowski JQ, Lee VM (2011) Dysregulation of the ALS-associated gene TDP-43 leads to neuronal death and degeneration in mice. J Clin Invest 121:726-738

Irwin D, Lippa CF, Rosso A (2008) Progranulin (PGRN) expression in ALS: An immunohistochemical study. J Neurol Sci 276:9-13

Johnson BS, McCaffery JM, Lindquist S, Gitler AD (2008) A yeast TDP-43 proteinopathy model: exploring the molecular determinants of TDP-43 aggregation and cellular toxicity. Proc Natl Acad Sci USA 105:6439-6444

Johnson BS, Snead D, Lee JJ, McCaffery JM, Shorter J, Gitler AD (2009) TDP-43 is intrinsically aggregation-prone and ALS-linked mutations accelerate aggregation and increase toxicity. J Biol Chem 284:20329-20339 
Josephs KA, Holton JL, Rossor MN, Godbolt AK, Ozawa T, Strand K, Khan N, Al Sarraj S, Revesz T (2004) Frontotemporal lobar degeneration and ubiquitin immunohistochemistry. Neuropathol Appl Neurobiol 30:369-373

Kabashi E, Valdmanis PN, Dion P, Spiegelman D, McConkey BJ, Vande VC, Bouchard JP, Lacomblez L, Pochigaeva K, Salachas F, Pradat PF, Camu W, Meininger V, Dupre N, Rouleau GA (2008) TARDBP mutations in individuals with sporadic and familial amyotrophic lateral sclerosis. Nat Genet 40:572-574

Kamrava M, Simpkins F, Alejandro E, Michener C, Meltzer E, Kohn EC (2005) Lysophosphatidic acid and endothelin-induced proliferation of ovarian cancer cell lines is mitigated by neutralization of granulinepithelin precursor (GEP), a prosurvival factor for ovarian cancer. Oncogene 24:7084-7093

Kanazawa M, Kakita A, Igarashi H, Takahashi T, Kawamura K, Takahashi H, Nakada T, Nishizawa M, Shimohata T (2011) Biochemical and histopathological alterations in TAR DNAbinding protein-43 after acute ischemic stroke in rats. J Neurochem 116:957-965

Kao AW, Eisenhut RJ, Martens LH, Nakamura A, Huang A, Bagley JA, Zhou P, de Luis A, Neukomm LJ, Cabello J, Farese RV Jr, Kenyon C (2011) A neurodegenerative disease mutation that accelerates the clearance of apoptotic cells. Proc Natl Acad Sci USA 108:4441-4446

Karch CM, Prudencio M, Winkler DD, Hart PJ, Borchelt DR (2009) Role of mutant SOD1 disulfide oxidation and aggregation in the pathogenesis of familial ALS. Proc Natl Acad Sci USA 106:7774-7779

Kleinberger G, Wils H, Joris G, Ponsaert P, Timmermans J-P, Van Broeckhoven C, Kumar-Singh S (2010) Increased caspase activation and decreased TDP-43 solubility in progranulin knockout cortical cultures. J Neurochem 115:735-747

Kraemer BC, Schuck T, Wheeler JM, Robinson LC, Trojanowski JQ, Lee VM, Schellenberg GD (2010) Loss of murine TDP-43 disrupts motor function and plays an essential role in embryogenesis. Acta Neuropathol 119:409-419

Kumar-Singh S, Van Broeckhoven C (2007) Frontotemporal lobar degeneration: current concepts and advances. Brain Res 17:104-114

Kumar-Singh S, Theuns J, Van Broeck B, Pirici D, Vennekens K, Corsmit E, Cruts M, Dermaut B, Wang R, Van Broeckhoven C (2006) Mean age-of-onset of familial Alzheimer disease caused by presenilin mutations correlates with both increased Abeta 42 and decreased Abeta40. Hum Mutat 27:686-695

Kumar-Singh S, Wils H, Kleinberger G, Janssens J, Pereson S, and Van Broeckhoven C (2009) Overexpression of wild-type TDP-43 leads to motor neuron degeneration and spastic paralysis in germline transgenic mice. Alzheimer's \& Dementia 5 (4) Supplement: 4-4

Kwiatkowski TJ, Bosco DA, Leclerc AL, Tamrazian E, Vanderburg CR, Russ C, Davis A, Gilchrist J, Kasarskis EJ, Munsat T, Valdmanis P, Rouleau GA, Hosler BA, Cortelli P, de Jong PJ, Yoshinaga Y, Haines JL, Pericak-Vance MA, Yan J, Ticozzi N, Siddique T, McKennaYasek D, Sapp PC, Horvitz HR, Landers JE, Brown RH Jr (2009) Mutations in the FUS/TLS gene on chromosome 16 cause familial amyotrophic lateral sclerosis. Science 323:1205-1208

Lagier-Tourenne C, Polymenidou M, Cleveland DW (2010) TDP-43 and FUS/TLS: emerging roles in RNA processing and neurodegeneration. Hum Mol Genet 19:R46-R64

Lehman NL (2009) The ubiquitin proteasome system in neuropathology. Acta Neuropathol 118:329-347

Li Y, Ray P, Rao EJ, Shi C, Guo W, Chen X, Woodruff EA III, Fushimi K, Wu JY (2010) A Drosophila model for TDP-43 proteinopathy. Proc Natl Acad Sci USA 107:3169-3174

Liau LM, Lallone RL, Seitz RS, Buznikov A, Gregg JP, Kornblum HI, Nelson SF, Bronstein JM (2000) Identification of a human glioma-associated growth factor gene, granulin, using differential immuno-absorption. Cancer Res 60:1353-1360
Lin WL, Dickson DW (2008) Ultrastructural localization of TDP-43 in filamentous neuronal inclusions in various neurodegenerative diseases. Acta Neuropathol 116:205-213

Lu Y, Ferris J, Gao FB (2009) Frontotemporal dementia and amyotrophic lateral sclerosis-associated disease protein TDP-43 promotes dendritic branching. Mol Brain 2:30

Mackenzie IR, Bigio EH, Ince PG, Geser F, Neumann M, Cairns NJ, Kwong LK, Forman MS, Ravits J, Stewart H, Eisen A, McClusky L, Kretzschmar HA, Monoranu CM, Highley JR, Kirby J, Siddique T, Shaw PJ, Lee VM, Trojanowski JQ (2007) Pathological TDP-43 distinguishes sporadic amyotrophic lateral sclerosis from amyotrophic lateral sclerosis with SOD1 mutations. Ann Neurol 61:427-434

Mackenzie IR, Neumann M, Bigio EH, Cairns NJ, Alafuzoff I, Kril J, Kovacs GG, Ghetti B, Halliday G, Holm IE, Ince PG, Kamphorst W, Revesz T, Rozemuller AJ, Kumar-Singh S, Akiyama H, Baborie A, Spina S, Dickson DW, Trojanowski JQ, Mann DM (2009) Nomenclature for neuropathologic subtypes of frontotemporal lobar degeneration: consensus recommendations. Acta Neuropathol 117:15-18

Malaspina A, Kaushik N, de Belleroche J (2001) Differential expression of 14 genes in amyotrophic lateral sclerosis spinal cord detected using gridded cDNA arrays. J Neurochem 77:132-145

Maquat LE (2004) Nonsense-mediated mRNA decay: splicing, translation and mRNP dynamics. Nat Rev Mol Cell Biol 5:89-99

McDonald KK, Aulas A, Destroismaisons L, Pickles S, Beleac E, Camu W, Rouleau GA, Vande VC (2011) TAR DNA-binding protein 43 (TDP-43) regulates stress granule dynamics via differential regulation of G3BP and TIA-1. Hum Mol Genet 20:1400-1410

Mishra M, Paunesku T, Woloschak GE, Siddique T, Zhu LJ, Lin S, Greco K, Bigio EH (2007) Gene expression analysis of frontotemporal lobar degeneration of the motor neuron disease type with ubiquitinated inclusions. Acta Neuropathol 114:81-94

Monami G, Gonzalez EM, Hellman M, Gomella LG, Baffa R, Iozzo RV, Morrione A (2006) Proepithelin promotes migration and invasion of 5637 bladder cancer cells through the activation of ERK1/2 and the formation of a paxillin/FAK/ERK complex. Cancer Res 66:7103-7110

Mukherjee O, Pastor P, Cairns NJ, Chakraverty S, Kauwe JS, Shears S, Behrens MI, Budde J, Hinrichs AL, Norton J, Levitch D, Taylor-Reinwald L, Gitcho M, Tu PH, Tenenholz GL, Liscic RM, Armendariz J, Morris JC, Goate AM (2006) HDDD2 is a familial frontotemporal lobar degeneration with ubiquitin-positive, taunegative inclusions caused by a missense mutation in the signal peptide of progranulin. Ann Neurol 60:314-322

Mukherjee O, Wang J, Gitcho M, Chakraverty S, Taylor-Reinwald L, Shears S, Kauwe JS, Norton J, Levitch D, Bigio EH, Hatanpaa KJ, White CL, Morris JC, Cairns NJ, Goate A (2008) Molecular characterization of novel progranulin (GRN) mutations in frontotemporal dementia. Hum Mutat 29:512-521

Neary D, Snowden JS, Gustafson L, Passant U, Stuss D, Black S, Freedman M, Kertesz A, Robert PH, Albert M, Boone K, Miller BL, Cummings J, Benson DF (1998) Frontotemporal lobar degeneration: a consensus on clinical diagnostic criteria. Neurology 51:1546-1554

Neumann M, Sampathu DM, Kwong LK, Truax AC, Micsenyi MC, Chou TT, Bruce J, Schuck T, Grossman M, Clark CM, McCluskey LF, Miller BL, Masliah E, Mackenzie IR, Feldman H, Feiden W, Kretzschmar HA, Trojanowski JQ, Lee VM (2006) Ubiquitinated TDP-43 in frontotemporal lobar degeneration and amyotrophic lateral sclerosis. Science 314:130-133

Nonaka T, Kametani F, Arai T, Akiyama H, Hasegawa M (2009) Truncation and pathogenic mutations facilitate the formation of intracellular aggregates of TDP-43. Hum Mol Genet. doi:10.1093/ hmg/ddp275 
Ou SH, Wu F, Harrich D, Garcia-Martinez LF, Gaynor RB (1995) Cloning and characterization of a novel cellular protein, TDP-43, that binds to human immunodeficiency virus type 1 TAR DNA sequence motifs. J Virol 69:3584-3596

Pereson S, Wils H, Kleinberger G, McGowan E, Vandewoestyne M, Van BB, Joris G, Cuijt I, Deforce D, Hutton M, Van BC, KumarSingh S (2009) Progranulin expression correlates with dense-core amyloid plaque burden in Alzheimer disease mouse models. J Pathol 219:173-181

Pesiridis GS, Tripathy K, Tanik S, Trojanowski JQ, Lee VM (2011) A "two-hit" hypothesis for inclusion formation by carboxylterminal fragments of TDP-43 protein linked to RNA depletion and impaired microtubule-dependent transport. J Biol Chem 286:18845-18855

Pirici D, van der Zee J, Vandenberghe R, Rademakers R, Dermaut B, Cruts M, Vennekens K, Cuijt I, Lübke U, Ceuterick C, Martin JJ, Van Broeckhoven C, Kumar-Singh S (2006) Characterization of ubiquitinated intraneuronal inclusions in a novel Belgian frontotemporal lobar degeneration family. J Neuropathol Exp Neurol 65:289-301

Plowman GD, Green JM, Neubauer MG, Buckley SD, McDonald VL, Todaro GJ, Shoyab M (1992) The epithelin precursor encodes two proteins with opposing activities on epithelial cell growth. J Biol Chem 267:13073-13078

Plun-Favreau H, Lewis PA, Hardy J, Martins LM, Wood NW (2010) Cancer and neurodegeneration: between the devil and the deep blue sea. PLoS Genet 6:e1001257

Polymenidou M, Lagier-Tourenne C, Hutt KR, Huelga SC, Moran J, Liang TY, Ling SC, Sun E, Wancewicz E, Mazur C, Kordasiewicz H, Sedaghat Y, Donohue JP, Shiue L, Bennett CF, Yeo GW, Cleveland DW (2011) Long pre-mRNA depletion and RNA missplicing contribute to neuronal vulnerability from loss of TDP-43. Nat Neurosci 14:459-468

Poorkaj P, Bird TD, Wijsman E, Nemens E, Garruto RM, Anderson L, Andreadis A, Wiederholt WC, Raskind M, Schellenberg GD (1998) Tau is a candidate gene for chromosome 17 frontotemporal dementia. Ann Neurol 43:815-825

Rademakers R, Eriksen JL, Baker M, Robinson T, Ahmed Z, Lincoln SJ, Finch N, Rutherford NJ, Crook RJ, Josephs KA, Boeve BF, Knopman DS, Petersen RC, Parisi JE, Caselli RJ, Wszolek ZK, Uitti RJ, Feldman H, Hutton ML, Mackenzie IR, Graff-Radford NR, Dickson DW (2008) Common variation in the miR-659 binding-site of GRN is a major risk factor for TDP43-positive frontotemporal dementia. Hum Mol Genet 17:3631-3642

Ratnavalli E, Brayne C, Dawson K, Hodges JR (2002) The prevalence of frontotemporal dementia. Neurology 58:1615-1621

Rovelet-Lecrux A, Deramecourt V, Legallic S, Maurage CA, Le Ber I, Brice A, Lambert JC, Frebourg T, Hannequin D, Pasquier F, Campion D (2008) Deletion of the progranulin gene in patients with frontotemporal lobar degeneration or Parkinson disease. Neurobiol Dis 31:41-45

Seelaar H, Rohrer JD, Pijnenburg YA, Fox NC, van Swieten JC (2011) Clinical, genetic and pathological heterogeneity of frontotemporal dementia: a review. J Neurol Neurosurg Psychiatry 82:476-486

Sell C, Dumenil G, Deveaud C, Miura M, Coppola D, DeAngelis T, Rubin R, Efstratiadis A, Baserga R (1994) Effect of a null mutation of the insulin-like growth factor I receptor gene on growth and transformation of mouse embryo fibroblasts. Mol Cell Biol 14:3604-3612

Sephton CF, Good SK, Atkin S, Dewey CM, Mayer P III, Herz J, Yu G (2010) TDP-43 is a developmentally regulated protein essential for early embryonic development. J Biol Chem 285:6826-6834

Shan X, Vocadlo D, Krieger C (2009) Mislocalization of TDP-43 in the G93A mutant SOD1 transgenic mouse model of ALS. Neurosci Lett 458:70-74
Shankaran SS, Capell A, Hruscha AT, Fellerer K, Neumann M, Schmid B, Haass C (2008) Missense mutations in the progranulin gene linked to frontotemporal lobar degeneration with ubiquitinimmunoreactive inclusions reduce progranulin production and secretion. J Biol Chem 283:1744-1753

Skibinski G, Parkinson NJ, Brown JM, Chakrabarti L, Lloyd SL, Hummerich H, Nielsen JE, Hodges JR, Spillantini MG, Thusgaard T, Brandner S, Brun A, Rossor MN, Gade A, Johannsen P, Sorensen SA, Gydesen S, Fisher EM, Collinge J (2005) Mutations in the endosomal ESCRTIII-complex subunit CHMP2B in frontotemporal dementia. Nat Genet 37:806-808

Spillantini MG, Murrell JR, Goedert M, Farlow MR, Klug A, Ghetti B (1998) Mutation in the tau gene in familial multiple system tauopathy with presenile dementia. Proc Natl Acad Sci USA 95:7737-7741

Sreedharan J, Blair IP, Tripathi VB, Hu X, Vance C, Rogelj B, Ackerley S, Durnall JC, Williams KL, Buratti E, Baralle F, de Belleroche J, Mitchell JD, Leigh PN, Al Chalabi A, Miller CC, Nicholson G, Shaw CE (2008) TDP-43 mutations in familial and sporadic amyotrophic lateral sclerosis. Science 319:1668-1672

Su JH, Nichol KE, Sitch T, Sheu P, Chubb C, Miller BL, Tomaselli KJ, Kim RC, Cotman CW (2000) DNA damage and activated caspase-3 expression in neurons and astrocytes: evidence for apoptosis in frontotemporal dementia. Exp Neurol 163:9-19

Tang W, Lu Y, Tian QY, Zhang Y, Guo FJ, Liu GY, Syed NM, Lai Y, Lin EA, Kong L, Su J, Yin F, Ding AH, Zanin-Zhorov A, Dustin ML, Tao J, Craft J, Yin Z, Feng JQ, Abramson SB, Yu XP, Liu CJ (2011) The growth factor progranulin binds to TNF receptors and is therapeutic against inflammatory arthritis in mice. Science 332:478-484

Tatom JB, Wang DB, Dayton RD, Skalli O, Hutton ML, Dickson DW, Klein RL (2009) Mimicking aspects of frontotemporal lobar degeneration and Lou Gehrig's disease in rats via TDP-43 overexpression. Mol Ther 17:607-613

Thinakaran G, Harris CL, Ratovitski T, Davenport F, Slunt HH, Price D, Borchelt DR, Sisodia SS (1997) Evidence that levels of presenilins (PS1 and PS2) are coordinately regulated by competition for limiting cellular factors. J Biol Chem 272:28415-28422

Trojanowski JQ, Dickson D (2001) Update on the neuropathological diagnosis of frontotemporal dementias. J Neuropathol Exp Neurol 60:1123-1126

Tsai KJ, Yang CH, Fang YH, Cho KH, Chien WL, Wang WT, Wu TW, Lin CP, Fu WM, Shen CK (2010) Elevated expression of TDP-43 in the forebrain of mice is sufficient to cause neurological and pathological phenotypes mimicking FTLD-U. J Exp Med 207:1661-1673

Van Broeck B, Van Broeckhoven C, Kumar-Singh S (2007) Current insights into molecular mechanisms of Alzheimer disease and their implications for therapeutic approaches. Neurodegener Dis 4:349-365

Van Damme P, Martens L, Van Damme J, Hugelier K, Staes A, Vandekerckhove J, Gevaert K (2005) Caspase-specific and nonspecific in vivo protein processing during Fas-induced apoptosis. Nat Methods 2:771-777

Van Damme P, Van Hoecke A, Lambrechts D, Vanacker P, Bogaert E, van Swieten J, Carmeliet P, Van Den Bosch L, Robberecht W (2008) Progranulin functions as a neurotrophic factor to regulate neurite outgrowth and enhance neuronal survival. J Cell Biol $181: 37-41$

Van Deerlin V, Leverenz JB, Bekris LM, Bird TD, Yuan W, Elman LB, Clay D, Wood EM, Chen-Plotkin AS, Martinez-Lage M, Steinbart E, McCluskey L, Grossman M, Neumann M, Wu IL, Yang WS, Kalb R, Galasko DR, Montine TJ, Trojanowski JQ, Lee VM, Schellenberg GD, Yu CE (2008) TARDBP mutations in amyotrophic lateral sclerosis with TDP-43 neuropathology: a genetic and histopathological analysis. Lancet Neurol 7:409-416 
Van Deerlin VM, Sleiman PM, Martinez-Lage M, Chen-Plotkin A, Wang LS, Graff-Radford NR, Dickson DW, Rademakers R, Boeve BF, Grossman M, Arnold SE, Mann DM, PickeringBrown SM, Seelaar H, Heutink P, van Swieten JC, Murrell JR, Ghetti B, Spina S, Grafman J, Hodges J, Spillantini MG, Gilman S, Lieberman AP, Kaye JA, Woltjer RL, Bigio EH, Mesulam M, Al-Sarraj S, Troakes C, Rosenberg RN, White CL III, Ferrer I, Llado A, Neumann M, Kretzschmar HA, Hulette CM, WelshBohmer KA, Miller BL, Alzualde A, de Munain AL, McKee AC, Gearing M, Levey AI, Lah JJ, Hardy J, Rohrer JD, Lashley T, Mackenzie IR, Feldman HH, Hamilton RL, DeKosky ST, van der Zee J, Kumar-Singh S, Van BC, Mayeux R, Vonsattel JP, Troncoso JC, Kril JJ, Kwok JB, Halliday GM, Bird TD, Ince PG, Shaw PJ, Cairns NJ, Morris JC, McLean CA, DeCarli C, Ellis WG, Freeman SH, Frosch MP, Growdon JH, Perl DP, Sano M, Bennett DA, Schneider JA, Beach TG, Reiman EM, Woodruff BK, Cummings J, Vinters HV, Miller CA, Chui HC, Alafuzoff I, Hartikainen P, Seilhean D, Galasko D, Masliah E, Cotman CW, Tunon MT, Martinez MC, Munoz DG, Carroll SL, Marson D, Riederer PF, Bogdanovic N, Schellenberg GD, Hakonarson H, Trojanowski JQ, Lee VM (2010) Common variants at 7p21 are associated with frontotemporal lobar degeneration with TDP-43 inclusions. Nat Genet 42:234-239

van der Zee J, Le Ber I, Maurer-Stroh S, Engelborghs S, Gijselinck I, Camuzat A, Brouwers N, Vandenberghe R, Sleegers K, Hannequin D, Dermaut B, Schymkowitz J, Campion D, Santens P, Martin JJ, Lacomblez L, De Pooter T, Peeters K, Mattheijssens M, Vercelletto M, Van den Broeck M, Cruts M, De Deyn PP, Rousseau F, Brice A, Van Broeckhoven C (2007) Mutations other than null mutations producing a pathogenic loss of progranulin in frontotemporal dementia. Hum Mutat 28:416

Vance C, Rogelj B, Hortobagyi T, De Vos KJ, Nishimura AL, Sreedharan J, Hu X, Smith B, Ruddy D, Wright P, Ganesalingam J, Williams KL, Tripathi V, Al-Saraj S, Al-Chalabi A, Leigh PN, Blair IP, Nicholson G, de Belleroche J, Gallo JM, Miller CC, Shaw CE (2009) Mutations in FUS, an RNA processing protein, cause familial amyotrophic lateral sclerosis type 6. Science 323:1208-1211

Wang WX, Wilfred BR, Madathil SK, Tang G, Hu Y, Dimayuga J, Stromberg AJ, Huang Q, Saatman KE, Nelson PT (2010) miR107 regulates granulin/progranulin with implications for traumatic brain injury and neurodegenerative disease. Am J Pathol 177:334-345

Watts GD, Wymer J, Kovach MJ, Mehta SG, Mumm S, Darvish D, Pestronk A, Whyte MP, Kimonis VE (2004) Inclusion body myopathy associated with Paget disease of bone and frontotemporal dementia is caused by mutant valosin-containing protein. Nat Genet 36:377-381

Wegorzewska I, Bell S, Cairns NJ, Miller TM, Baloh RH (2009) TDP-43 mutant transgenic mice develop features of ALS and frontotemporal lobar degeneration. Proc Natl Acad Sci USA 106:18809-18814

Willnow TE, Petersen CM, Nykjaer A (2008) VPS10P-domain receptors-regulators of neuronal viability and function. Nat Rev Neurosci 9:899-909
Wils H, Kleinberger G, Joris G, Cuijt I, Engelborghs S, De Deyn P, Martin J-J, De Vijlder T, Witters E, Van Broeckhoven C, KumarSingh S (2008) Generation of FTLD-U Mouse Models: conditional Grn knockout and wild-type and mutant hTDP-43 overexpressing mice. Dement GeriatrCogn Disord 26(suppl 1):11

Wils H, Kleinberger G, Janssens J, Pereson S, Joris G, Cuijt I, Smits V, Ceuterick-de GC, Van BC, Kumar-Singh S (2010) TDP-43 transgenic mice develop spastic paralysis and neuronal inclusions characteristic of ALS and frontotemporal lobar degeneration. Proc Natl Acad Sci USA 107:3858-3863

Winton MJ, Van Deerlin VM, Kwong LK, Yuan W, Wood EM, Yu CE, Schellenberg GD, Rademakers R, Caselli R, Karydas A, Trojanowski JQ, Miller BL, Lee VM (2008) A90V TDP-43 variant results in the aberrant localization of TDP-43 in vitro. FEBS Lett 582:2252-2256

Wu LS, Cheng WC, Hou SC, Yan YT, Jiang ST, Shen CK (2010) TDP-43, a neuro-pathosignature factor, is essential for early mouse embryogenesis. Genesis 48:56-62

Xu SQ, Tang D, Chamberlain S, Pronk G, Masiarz FR, Kaur S, Prisco M, Zanocco-Marani T, Baserga R (1998) The granulin/epithelin precursor abrogates the requirement for the insulin-like growth factor 1 receptor for growth in vitro. J Biol Chem 273:2007820083

Xu YF, Gendron TF, Zhang YJ, Lin WL, D'Alton S, Sheng H, Casey MC, Tong J, Knight J, Yu X, Rademakers R, Boylan K, Hutton M, McGowan E, Dickson DW, Lewis J, Petrucelli L (2010) Wildtype human TDP-43 expression causes TDP-43 phosphorylation, mitochondrial aggregation, motor deficits, and early mortality in transgenic mice. J Neurosci 30:10851-10859

Yin F, Banerjee R, Thomas B, Zhou P, Qian L, Jia T, Ma X, Ma Y, Iadecola C, Beal MF, Nathan C, Ding A (2010) Exaggerated inflammation, impaired host defense, and neuropathology in progranulin-deficient mice. J Exp Med 207:117-4

Young MR, Matthews JP, Kanabrocki EL, Sothern RB, RoitmanJohnson B, Scheving LE (1995) Circadian rhythmometry of serum interleukin-2, interleukin-10, tumor necrosis factor-alpha, and granulocyte-macrophage colony-stimulating factor in men. Chronobiol Int 12:19-27

Zanocco-Marani T, Bateman A, Romano G, Valentinis B, He ZH, Baserga R (1999) Biological activities and signaling pathways of the granulin/epithelin precursor. Cancer Res 59:5331-5340

Zhang YJ, Xu YF, Dickey CA, Buratti E, Baralle F, Bailey R, Pickering-Brown S, Dickson D, Petrucelli L (2007) Progranulin mediates caspase-dependent cleavage of TAR DNA binding protein-43. J Neurosci 27:10530-10534

Zhang YJ, Xu YF, Cook C, Gendron TF, Roettges P, Link CD, Lin WL, Tong JM, Castanedes-Casey M, Ash P, Gass J, Rangachari V, Buratti E, Baralle F, Golde TE, Dickson DW, Petrucelli L (2009) Aberrant cleavage of TDP-43 enhances aggregation and cellular toxicity. Proc Natl Acad Sci USA 106:7607-7612

Zhou J, Gao G, Crabb JW, Serrero G (1993) Purification of an autocrine growth factor homologous with mouse epithelin precursor from a highly tumorigenic cell line. J Biol Chem 268:10863-10869 